\title{
Weddings in Catholic strong belief communities: a qualitative examination of Catholic deep-faith spouses' experience of their wedding.
}

\author{
PHILLIPS, R.
}




\title{
Weddings in Catholic Strong Belief Communities:
}

\section{A Qualitative Examination of Catholic Deep-Faith Spouses' Experience of their Wedding}

\begin{abstract}
Previous research indicated that traditional rituals, social codes and contemporary norms strongly influence a wedding's construction. This project aimed to understand how members from strong belief Roman-Catholic communities negotiate between social influences impacting their wedding. Interpretative Phenomenological Analysis of eight interviews revealed how couples construct and communicate pertinent aspects of a combined self. The participants' conception of the wedding was perceived as a representation of their 'true' selves and strongly informed external religious authorities. Engaging in religious practices enabled participants recreate group expectations and norms and internalize them as personal mental property. The Community's support and acceptance of the individual stabilised and affirmed their religious-identity, causing it to be shielded from potentially conflicting out-group expectations. This allowed the individual to express their identity regardless of context. The wedding in this sense became an expression of their religious identity and reaffirmed the bond with their Roman-Catholic strong-belief group.
\end{abstract}

\section{Keywords: Wedding, Self, Subcultures, Strong-Faith Communities, Identity}

1 lthough marriages and weddings occur in the majority of world cultures (Rosenblatt \& Anderson, 1981) research tends to neglect this important area of social life. Before 1990 academic examinations of weddings were largely confined to anthropology, where weddings were examined as rituals of passage that are culturally dependent in their construction (Bell, 1997). Interestingly, psychological insight into how fiancées balance cultural norms, social qualities and the individual's and couple's representations of themselves in setting up their weddings are rare. This lack of research especially applies to members of subcultures like strong belief Roman-Catholic Communities (i.e. Loretto, Opus Dei, Commune E Liberazione). These Communities are characterized by its members, who intensely study church rules, engage themselves actively in belief and live according to the Catechesis, the book of religious instructions (i.e. 'Theology of the Body' by Pope John Paul II, 1997). Through the adoption of the Christian concept of love, which associates God to representing ultimate love (Paul, 1997), a wedding becomes a celebration of the marriage's indissoluble bond willed and blessed by God (Liberia Editrice Vaticana, 2000). Although this concept deviates from the popular westernmainstream society's perception, scientific studies have failed to address the Community members' experiences relative to the planning and design of their wedding.

In light of this, the present study examines how eight recently married Community spouses perceive their wedding preparation and celebration. The research's focus involves investigating the construction of the participants' self, while being both a couple and a part of the community. In doing so, the present project examines the representation of the individual's self in the context of a wedding - being an important socio-cultural as well as religious ceremony.

\section{Mainstream-cultural influences on individual perceptions}

\footnotetext{
Journal Title

Volume \#, Issue \#, 20\#\#, https://<websitelink>.com

(C) Common Ground Research Networks, Author(s) Name(s), All Rights Reserved.

Permissions: cgscholar.com/cg_support

ISSN: \#\#\#\#-\#\#\#\# (Print), ISSN: \#\#\#\#-\#\#\#\# (Online)

https://doi.org/\#\#\#\#\#\#\#\#\#\#\#\#\#\#\#\#\#\#\# (Article)
} 
Research indicates that the structure and frames of references concerning the set-up of a wedding are influenced by contemporary norms and ideals, many of which are conveyed through advertisements and media (i.e. Corrado 2002; Otnes, Lowrey \& Shrum, 1997; Otnes \& Scott, 1996; Otnes \& Pleck, 2003). These ideals promote 'white weddings', referring to weddings inspired by US culture, and represent them as the proper way to get married all around the world (Pleck, 2000). Studies, which give evidence for mass-media communication fostering personal and social changes (i.e. Bandura, 2012); inspired scholars such as Nelson and Deshpande (2004) to suggest "a homogenisation of the wedding ritual" (p. 126) due to the global dominance of western mainstream weddings and bride-typical references in US films, series and TV-shows (Ingraham , 2008). In order to be "your day to be princess" (Otnes et al., 1997, p. 85) or the "most important day of my life" (Corrado, 2003, p. 22), a range of secular wedding specialists are employed and act as agents and mediators of contemporary norms such as western mainstream weddings (Leeds-Hurwitz, 2002) and cultural traditions.

Nelson and Deshpande (2004) argue that to be different from a dominant culture allows a person to deviate from cultural customs and classic 'white wedding' norms. This notion may not be exclusive for different ethnic cultures but also applicable to religious cultures. In a Roman Catholic Christian context, literature opposes mass-media influencing Christian weddings, as it suggests they differ from western 'white weddings' in their core (cf. Rubio, 2003). Roman Catholic Christian weddings celebrate the marriage, the decision to completely give oneself in love to the other, as well as to embrace all that the spouse is, and thus to become one body (Libreria Editrice Vaticana, 2000). Mainstream 'white weddings', in contrast, are considered to be a personalized, lavish, romantic feast (Rubio, 2003). Therefore, deviating from mainstream western 'white wedding' norms and cultural traditions could result in a difference in the underlying structure of strong belief Community members' weddings and marriages. Rubio (2003) suggests that TV and mass-media are neither sufficient for the spiritual preparation of a marriage nor for planning the wedding ceremony. A vision and insight of marriage can only be provided by a proper preparation, which also includes reading and discussing theological books. These are assumed to shape the wedding celebration (Rubio, 2003). Hence ritual wedding specialists like priests could be assigned to greater influence in the construction of a wedding than secular wedding specialists.

In addition, the Roman Catholic Christian perception of beauty may suggest that mundane wedding experts are less involved in Community weddings. Beauty, in a Christian context, is associated with authentic trueness, affection, goodness and God himself (West, 2003). Therefore, the bride's beauty too is perceived as the radiation of her goodness (cf. ibid). A husband, who appreciates, desires and takes care of his wife's beauty, loves her body as an expression of her Christian beauty, which indicates attributes and qualities of the moral and spiritual order associated with holiness (West, 2003). This stands in contrast to the idea of squeezing the bride's body, making it fit into a gown to create a flawless beautiful image (cf. Corrado, 2002).

The question of where and how Roman-Catholic strong belief Community members follow these concepts has not yet been scientifically investigated. If members were strongly influenced by contemporary norms it would suggest either a limited affiliation to the group or that the group itself implemented mass-media norms, adapting to mass-society. If, however, the Christian theoretical constructs underpin the psychological meaning for couples preparing Community weddings, this would suggest that those couples balance sub-cultural, cultural and social

\footnotetext{
Journal Title

Volume \#, Issue \#, 20\#\#, https://<websitelink>.com

(C) Common Ground Research Networks, Author(s) Name(s), All Rights Reserved.

Permissions: cgscholar.com/cg_support

ISSN: \#\#\#\#-\#\#\# (Print), ISSN: \#\#\#\#-\#\#\#\# (Online)

https://doi.org/\#\#\#\#\#\#\#\#\#\#\#\#\#\#\#\#\#\#\# (Article)
} 
expectations and the expression of themselves in planning their wedding. It is likely that the couple has to face discrepancies in negotiating these expectations at some point in planning, especially as they might want to contribute to the strong belief Community's culture, westernmainstream culture and friends' or family's culture. This can be related to cultural ambivalence, which originates in conflicting cultural values (Hajda, 1968).

\section{Sociocultural influences on individual perceptions}

Influence on the selection of wedding rituals may derive from families and friends. Studies indicate that culture-typical sets of specific rituals of important celebrations such as weddings are not only passed on by elders, relatives, parents and friends but also expected by these people (Rosenthal \& Marshall, 1988). Therefore, rituals are used by cultural groups to communicate and transfer complex ideas to its members without need for explanation and, by doing so, reaffirm social bonds with the group (Turner, 1969; Van Gennep, 1960). However, spouses from strong belief Communities may not integrate culture-typical sets of specific rituals as conforming to those rituals that are defined by their subculture.

This may particularly be the case as the family of those who have joined strong belief Communities are unlikely to be part of the same Community. Therefore, expectations of which rituals are to be integrated and how these rituals are to be carried out may differ. From a Catholic perspective, a wedding is the celebration of a sacral sacrament, of thankfulness for the gift of received love (Paul, 1997). As sacred performances can be made profane by modification (Bouissac, 1990), similarities in the ceremony's structure within strong-belief communities can be assumed and are likely to deviate from worldly, mundane friends' and family's expectations. This could cause intrapersonal conflicts in those getting married and interpersonal arguments with significant friends and family. If an individual perceives a need to express multiple social roles simultaneously, this may result in conflicting emotions, known as sociological ambivalence (Lopata, 1991; Zananiecki, 1965). Such experiences have previously been related to planning a wedding ceremony (i.e. Otnes, Lowrey \& Shrum, 1997). The question of how engaged strong belief Community couples balance differing expectations from their Community and their wider family and friends, and how they cope with potential intra- and interpersonal conflicts has not yet answered and will be addressed in the current research.

Studies that address coping strategies and sources of help in planning indicate three main areas of conflicts concerning customs and values (cf. Otnes et al., 1997): The first is a bride's resistance to a custom. This reflects the difference between traditional customs, expected to be integrated by culture, and those that the bride wanted to include. Secondly, conflicts can also originate in desires for self-expression. These conflicts refer to expressing one's own identity through customs. Lastly, the ambivalence of customary artifacts, which the bride was not able to provide can cause conflicts. This refers to a bride's inability to contribute to a custom she feels affiliated with. Brides handled these problems by giving in (resignation), alteration of customs (modification) or by refusing to include customs or symbols (defiant non-purchase). Research in a cross-cultural setting, outlines similar findings. Nelson and Deshpande (2004) indicate that cross-cultural couples also employ resignation, modification and defiant non-purchase coping strategies. Cross-cultural spouses, however, also had an additional source for emotional support: Virtual communities like wedding-message boards. In conclusion, sharing similar cross-cultural

\footnotetext{
Journal Title

Volume \#, Issue \#, 20\#\#, https://<websitelink>.com

(C) Common Ground Research Networks, Author(s) Name(s), All Rights Reserved.

Permissions: cgscholar.com/cg_support

ISSN: \#\#\#-\#\#\#\# (Print), ISSN: \#\#\#\#-\#\#\#\# (Online)

https://doi.org/\#\#\#\#\#\#\#\#\#\#\#\#\#\#\#\#\#\#\# (Article)
} 
ambivalent experiences may create trust that make brides-to-be to refer to help from virtual friends (rather than to their mothers), real-life friends or wedding planners.

Sharing the same experiences as a factor in the selection of sources of help would suggest that Community spouses' rely on their group for help. Research, however, failed to contribute to an understanding of how engaged members of religious groups cope with conflicts and resolve them. Possible group-typical similarities concerning additional sources of help, such as advice and information, might be salient and are analyzed in the current study.

\section{Subcultural influences on individual perceptions}

Groups can influence an individual's perception of what is considered true and what is considered false (Sherif, 1935). When applied to weddings in strong belief Communities this would suggest that Community friends, who form the spouses' in-group may have profound influence on the way weddings are carried out. Essentially, situating oneself in social relations creates an identity (Gross \& Stone, 1964; Stone, 1962) that allows one to create meaning from an experience, find a frame of reference and structure mass society (Klapp, 1969). The notion that individuals may be more likely to share social realities with people of their own category (Turner, 1985), would suggest the presence of an interaction between the social and individual identity in generating ideas of how performances should be carried out and what a Christian wedding should look like.

Potential similarities in the preparation of Community weddings and in the ceremonies themselves also allow the interpretation of an identity to be a conscious and constantly remade expression of oneself to fit the social situation (Goffman, 1959). The individual's behaviour in this context can be linked to a performance, which allows a person to evoke specific impressions of one's self in another's mind, which in Goffman's (1959) terms would be referred to as Front Stage performances. When no audience is present, people are supposed to engage in Back Stage behaviour, which can be inconsistent with the behaviour with an audience present. In the context of the strong-belief Community this would suggest, that spouses act according to expectations from the social circle present, which could explain similarities in the Community weddings' construction.

If a wedding ceremony, however, expresses elements important to the individual's own selfconcept rather than to the Community's, a more individual wedding-script would be salient and supporting a different theory of identity construction. Instead of emerging through social interactions to fulfil the individual's demand of structure, an identity could be groupindependently grounded on the consequence of daily experiences, in accordance with Spinelli's (2001) theory of the self. Spinelli supposes the self to be a constantly remade fluid and dynamic entity, which does not explicitly distinguish between the impact of perceived social situations or affiliation group. As only a part of the self is composed by how the subject processes experiences with others and the meaning given to interpersonal situations in the context of interpersonal

Journal Title

Volume \#, Issue \#, 20\#\#, https://<websitelink>.com

(C) Common Ground Research Networks, Author(s) Name(s), All Rights Reserved.

Permissions: cgscholar.com/cg_support

ISSN: \#\#\#\#-\#\#\# (Print), ISSN: \#\#\#\#-\#\#\#\# (Online)

https://doi.org/\#\#\#\#\#\#\#\#\#\#\#\#\#\#\#\#\#\#\# (Article) 
relationships (Tajfel, 1996), the influence that groups have on the self may be therefore deemphasised. In the Roman-Catholic strong belief Community context, this would mean a decreased influence from the groups' expectations and incorporation of group values into the wedding ceremony. Therefore, the level of response and adaption to group values is assumed to be less, as the self is not built upon it completely.

\section{Methods}

\section{Participants}

Eight married persons (four married couples) from Roman Catholic strong belief Communities, were recruited by opportunity sampling (cf. Table 1). A homogenous sample was created with an appropriate sample size for in-depth examinations of psychological thinking patterns and understandings (Patton, 1990) and for interpretative phenomenological analysis (IPA, Smith, 2008) to be employed. All participants reported to spend at least one hour a day in prayer and to attending worshipping ceremonies of one or more strong-belief Roman-Catholic Community more than once week from their engagement to the day the interview took place.

\section{Insert Table 1 about here}

\section{Interviews and Procedure}

The present study required participants to provide detailed descriptions of their first-hand experiences and their reactions to those experiences. Therefore, semi-structured, biographic narrative interviews (Wengraf, 2001) were utilised. Eight face-to-face interviews were conducted individually, each of them lasting between 60 and 90 minutes. The interview schedule was structured in three sub-sessions.

The first stage promoted participants to speak freely about their lived experiences on the investigated phenomena. The second part consisted of questions that were based upon the participants' responses from the initial question. These follow-up probes encouraged the participant to elaborate information related to the area of the study's interest to further clarify the respondent's meanings (Smith \& Eatough, 2007). The final sub-section comprised specific questions, based on pre-existing knowledge, by integrating information from the reviewed literature. These questions explored the perceived self during the preparation for marriage, its conscious expression during the wedding celebration and influences from Community members on it.

The interviews were conducted in a three weeks' time-period. After the interviews were audiotape recorded, transcribed verbatim and sent to participants for checking, the interviews were analysed with IPA (Smith, 2008).

\section{Data Analysis}

Each transcript was analysed individually by IPA (Smith, 2008, Smith, Jarban \& Osborne, 1999). Deriving from the phenomenological tradition (Hussler, 1925), IPA helps to understand the

\footnotetext{
Journal Title

Volume \#, Issue \#, 20\#\#, https://<websitelink>.com

(C) Common Ground Research Networks, Author(s) Name(s), All Rights Reserved.

Permissions: cgscholar.com/cg_support

ISSN: \#\#\#-\#\#\#\# (Print), ISSN: \#\#\#\#-\#\#\#\# (Online)

https://doi.org/\#\#\#\#\#\#\#\#\#\#\#\#\#\#\#\#\#\#\# (Article)
} 
holistic meaning of phenomena through the description of subjective perceptions. By the researcher's attempt to describe the content of the data, and, in a further step, its psychological significance and key psychological constructs, emerging key themes were identified (cf. also Smith, Jarmon \& Osborn, 1999). This made it possible to reveal the underlying psychological meaning behind the respondents' answers and allows to group thinking patterns and perceptions into categories. The researcher could interact in an interpretive way at this stage, whilst interpretations remained grounded in the respondents' answers. Through cross-data analysis of the transcripts, superordinate- and sub-themes were established. To be certain that the themes were grounded in the participants' answers, the transcripts were viewed in a back and forth manner and have been peer reviewed by one non-psychologist scholar.

\section{Results}

Extracts from participants' narratives have been used to illustrate the factors involved in the individual's constitution of an identity within a community and its expression during the wedding ceremony. Common themes emerged which were ordered chronologically and presented in the following findings. The results show how an active engagement with belief in a Community contributes to an individual's self-discovery and self-perception. By stabilising this process through the affiliation group's support and acceptance, the Community's values are recreated as personal mental property. These values superseded the mundane cultural expectations, especially concerning the wedding celebration as the following will show.

\section{Conceptualisations of a good relationship}

All participants understood a good relationship being grounded on Christian values, specifically unconditional love according to the discipleship of Christ. Being similar to the definition found in Christian literature (e.g. West, 2003), Community members try to realize this theoretical concept of a Christian relationship by focusing on God more than on the partner. John for example, commented as follows:

'Our relationship is Christian, which means we follow God's rules, invite God into our relationship and into ourselves, look actively for God, love one another through God. I couldn't imagine having this kind of great relationship with Helen without Christianity. It is fundamental.'

Living according to these values means that Christ, God and the Holy Spirit come first. The Holy Trinity, being perceived as ultimate, eternal, limitless and pure love make an interpersonal relationship only possible if God is part of it and rather the more important partner. As two persons in the relationship focus their love on God, he becomes the means of enhancing it between them. According to the belief that 'there is no love without God' (Andy), two kinds of love seemed to exist in the participants' accounts: One between an individual and God and another between two individuals, in which God's love is always implicit. Before one is able to love another though, one has to love God, as only through him, the ultimate origin of love, one can evoke and maintain interpersonal love. That, according to participants is the nature of a good relationship. Helen explained:

\footnotetext{
Journal Title

Volume \#, Issue \#, 20\#\#, https://<websitelink>.com

(C) Common Ground Research Networks, Author(s) Name(s), All Rights Reserved.

Permissions: cgscholar.com/cg_support

ISSN: \#\#\#\#-\#\#\#\# (Print), ISSN: \#\#\#\#-\#\#\#\# (Online)

https://doi.org/\#\#\#\#\#\#\#\#\#\#\#\#\#\#\#\#\#\#\# (Article)
} 
'At first, there was and is my love for God. Then God sent me someone. I didn't feel attracted to him straight away. But somehow, I got to know him better and I started loving him. Hence it started with an emotion, which lead to a decision.'

Faith becomes an instrument that allows the partnership, and all the implicated emotions, to grow within themselves. Through faith, a relationship is perceived as being 'not a relationship between two human beings anymore, but consisting of three parts: God, your partner and you' (Aaron). This perception allows the two partners to lose themselves in this love and remove all worldly desires and ambitions from their being, or in Jane's words, to make oneself 'independent from everything [...] because of [the] spiritual attachment to God'. This selflessness makes them free not only from personal desires but from the need to have any ambitions regarding their life, for the unwavering trust in God is enough. Aaron summarised:

'We will go with God, wherever he might take us. We will accept whatever he might give us, because we know that we can rely on him. He will care for us and provide us with everything we need."

Trust, as being the only thing people need for gaining personal satisfaction through a sense of fulfilment in all situations, also gives foresight of how Community members engage in constructing and preparing the wedding ceremony. People, living according to these principles, serve as an example next to informing about this attitude. They step in as friends and priests from Communities or as Christian family members, having a highly influential effect on the individuals' perception of a loving and good relationship. John claimed:

II have a couple of friends in the Community, who really have a good relationship, rooted in God.[...] But the [religious] brothers too, interact with each other with this fraternal love. They are a living example for how you can live love. This love is pretty much the same as marital love. Because it is more than only passion. It is companionship, unconditional and understanding love.'

Hence, more than finding and creating their own way to act in the relationship, Community members rather follow predetermined ideas. Experiences regarding the reference's group benevolent interactions affirm the individual in the decision to adjust their own behaviour. As this way of social interaction connects to the values, taught by the Community and internalised by its members, it is perceived as worth striving for. Supplementary, it can be reinforced by theoretical background knowledge provided by Christian books. Engaging with the information either in a passive way by 'understanding through reading the Theology of the Body' (Sharon) or proactively by 'discussing the theological books with priests' (Sue), supports the revision of the couple's identity according to the group's values. Helen declared:

'We learned what marriage, as a sacrament, really means [...] since we spoke about the books the priests had given us, during our religious lessons. We learned that God is always present in our relationship, especially when we get married, but also that we have to look for him and pray for love. That's our duty.'

For living according to these values, it is necessary that the partner represents a similar attitude, as 'it's easier to experience and live in divine love with a Christian partner' (Jane).

\footnotetext{
Journal Title

Volume \#, Issue \#, 20\#\#, https://<websitelink>.com

(C) Common Ground Research Networks, Author(s) Name(s), All Rights Reserved.

Permissions: cgscholar.com/cg_support

ISSN: \#\#\#-\#\#\#\# (Print), ISSN: \#\#\#\#-\#\#\#\# (Online)

https://doi.org/\#\#\#\#\#\#\#\#\#\#\#\#\#\#\#\#\#\#\# (Article)
} 
Therefore, the development of a couple's shared identity according to the Community's values is, next to being influenced by the it, reciprocally supported and intensified by their partners

\section{The decision to get married}

According to the belief that 'God wants [humans] to be happy' (Jane), in the choice to get married all participants dedicated and subjected their own freedom to God. Only through the experience of a call and hence attributing an active engagement with God, individuals know to be on the right divine way, as Aaron demonstrated:

'I didn't know whether to get married or not. (...) And then I spoke with Pater Thomas. I told him about my worries and he said something that went straight into my heart, influencing my whole future decisions: "Aaron, don't be afraid." It felt just as if God, the Lord and almighty father himself had spoken to me, and then I had the clarity of mind and peace in my heart to ask Jane to marry me.'

Therefore, ultimate trust in God answers the craving for guidance and, seen more generally, the desire for a sense within difficult situations and decisions. This especially accounts for the decision to get married, as the option of divorce is rejected. More than asking for God's affirmation, participants strived for it, being in a state of insecurity. Helen, for example:

'I was concerned, whether I was actually able to make a decision like that. [..] And the [Community] couple said: "It's good that you see marriage as something really big and life changing! And God will tell you whether you should get married and when! You will experience it!' And it happened exactly like that!'

In a sense, one could argue that rather than the individual taking complete ownership of a decision, it is passed over to God to some extent, and also is influenced by an authoritative member of the religious subculture. Through this, the individual's need for security is fulfilled, as, seen globally, faith turns uncertainty into a positive conviction. Finding security through a state of insecurity, which is expressed by dissociation from one's own decisions and absolving the self from own expectations on behalf of the divine plan, might appear as a contradiction. One could argue that the individual is exposing oneself to greater insecurity by dedicating oneself to God, putting their own desires behind the divine, unknown plan. However, in doing so, individuals perceive that faith turns fears and doubts into strength by attributing a positive purpose and the experience of final happiness to life events, which are willed by God. Moreover by committing oneself and all the life's projects to God, is perceived as actively transforming the individual, as 'by opening yourself to God's plans, he changes your heart, your desires' (Sue), leading to the rightful place, portrayed in Daniel's response:

'You have to accept [life events] and modify your plans, because they might not be, what God wants you to do or have. As God wants you to be happy, he puts you in a place, you are going to be happy. You can trust him. You have to believe that your own plans might not lead you to happiness, that they may cause just the opposite.'

\footnotetext{
Journal Title

Volume \#, Issue \#, 20\#\#, https://<websitelink>.com

(C) Common Ground Research Networks, Author(s) Name(s), All Rights Reserved.

Permissions: cgscholar.com/cg_support

ISSN: \#\#\#\#-\#\#\# (Print), ISSN: \#\#\#\#-\#\#\#\# (Online)

https://doi.org/\#\#\#\#\#\#\#\#\#\#\#\#\#\#\#\#\#\#\# (Article)
} 
Hence individuals perceive themselves to know that everything will be fine as long as they actively seek and follow the divine path, the predetermined way, which God made for them personally. This especially accounts for marriage. Sharon explained:

'Even though one wakes up in the morning and feels being taken for granted and as if everything -the household and so on - is left up to oneself again, one knows that everything will be good, because have experienced the call from God. He wanted me to get married. I will be happy. Maybe today, not so much, but tomorrow - as this was his plan for me.'

The sense of God's call accompanies Community members for life, which is more salient in difficult situations and evokes positive feelings of reassurance by focusing on the affirmation of being on the divine path. All participants reported having had a sense of a divine call. It was either related to the voice of an authority, as in Aaron's case, who perceived the priest as a medium, which officiated between him and God, or it can be experienced more directly, as God being apparent in one's decision. In Helen's case the call was related to God being an agent in herself. By perceiving him as giving her 'the answers [regarding questions during marriage preparation], showed [her] that he wanted [her] to get married to John'. Ascribing mental process like imaginativeness, defined by 'thoughts, [which] are suddenly there-they make sense and you don't know where they came from' (Helen), to God, allows finding security through faith. Also the feeling of the divinity's mere presence in a decision can be sufficient to feel affirmed by God. Daniel, for example 'knew that God wanted [them] to go the path of life together' by a 'feeling [...] difficult to explain'.

\section{The preparation for marriage}

After experiencing a call from God, all participants reported engaging in very similar religious practices to prepare for marriage spiritually. Namely, these were intensive praying, reading Christian literature and attending the Community's preparation course. Through these religious acts participants felt they both exposed and returned to one's true self. Therefore, a complete devotion to God evokes the ability to see oneself in a new light, as Helen demonstrated:

'During the spiritual preparation we were able to get to know our true selves better and discover ourselves in a spiritual way through prayer'.

This seeking of a true identity is a way of self-realization that, in turn, enables them to feel pure and contented with their state of being and with each other. Hence the longing for truthfulness which is salient in this attitude, is attributed to be answered by God, according to Sr. Edith Stein (2000): 'God is truth. All who seek truth seek God, whether this is clear to them or not'. Experiencing truth, the real identity, and in the highest instance God, is assumed as being only possible in a state of purity, or in Jane's words:

'I was able to see real beauty. This was because my head, my soul and my heart were clear again'.

This explains why Community members engage in rituals of psychological and physical asceticism like fasting, praying, special nine to 30 day novenas and refraining from physical

Journal Title

Volume \#, Issue \#, 20\#\#, https://<websitelink>.com

(C) Common Ground Research Networks, Author(s) Name(s), All Rights Reserved.

Permissions: cgscholar.com/cg_support

ISSN: \#\#\#\#-\#\#\#\# (Print), ISSN: \#\#\#\#-\#\#\#\# (Online)

https://doi.org/\#\#\#\#\#\#\#\#\#\#\#\#\#\#\#\#\#\#\# (Article) 
contact such as kissing. Aaron took the break-up of his first engagement to Jane as an example of the negative consequences of shifting away the focus from God:

'We had already been engaged once and broke up because we had been too focused on our own desires and on what others might have thought. [...]Everybody has to decide for themselves [concerning kissing during the engagement period], but in my experience, if you are kissing, you are less focused on each other and God. The time you spend together [while refraining from kissing] is far more intense, on a cognitive and spiritual level. As time goes by, you feel somehow freed from your desires and have more respect for your own and other ones' body.'

Through rituals of purification individuals regard themselves and the partner in a transcendent way by practicing self-denial and self-control. By being intent on their spirituality they let their partner into their very private relationship with God and in conclusion intensify both their interpersonal relationship and their relationship as a couple with God. Therefore, the partner benefits as a by-product of this engagement, as it is associated with unmasking the partner's authentic identity, portrayed in Helen's response:

If you pray together, you experience a deeper relationship, which grows. You get to know your partner in a deeper way. Again this is an experience, difficult to describe. You gain security because you know you can trust your partner and during prayer he is just as open, as you are. It is his true identity he reveals, just as I reveal my true identity to him and to God!'

Allowing the partner to find and be their true self in God, gives them absolute freedom. So, while marriage binds two people together, it also provides the safety and means for each partner to be their individual, true self, accepted and supported by the partner.

\section{The role of religious authorities}

The belief that a wedding implies a deeper meaning, being 'more than a worldly feast' (Andy), contributes to the participants' perception of its increased spiritual value. This evokes the deliberate conformation to authoritative voices. As participants adjudge teaching authority to priests, assuming them to know best, they are the first contact persons after getting engaged, as Aaron explained:

'We went to the Community priest afterwards [...]. The priest explained how and why you do various things. This was useful. We got a very distinct insight, through his explanation.'

Hence priests oversee and guide the individual into the spiritual preparation, to show members what is most important. In order to not only have a spiritually sound wedding but also such a married afterlife also frater are accepted as being appropriate authoritative voices, who inform the couple, as Helen portrayed in her answer:

'The brothers gave us spiritual marriage preparation books and we spoke about them. Actually this was really important. I think I learned what marriage as a sacrament really means.'

\footnotetext{
Journal Title

Volume \#, Issue \#, 20\#\#, https://<websitelink>.com

(C) Common Ground Research Networks, Author(s) Name(s), All Rights Reserved.

Permissions: cgscholar.com/cg_support

ISSN: \#\#\#\#-\#\#\# (Print), ISSN: \#\#\#\#-\#\#\#\# (Online)

https://doi.org/\#\#\#\#\#\#\#\#\#\#\#\#\#\#\#\#\#\#\# (Article)
} 
The intense cognitive engagement with the Roman-Catholic expectations regarding marriage, during the spiritual preparation, evoked the establishment of a personal meaning and, as a consequence, identification with the spiritual ideas of the group. Through re-thinking and the attempt to understand the priests' thought processes and literature, unknown matter becomes integrated in the self-concept, answering the longing for doing something correctly and properly in order to find trueness and, ultimately, to find God in marriage. Sharon, for example, claimed:

'Speaking with the priests during the preparation period, changes you, changes your heart, your understanding. You get this feeling, that what the priests say is rightful. It's like an adventure, which you can only experience when you're open for it. When you start to understand, you also start to change into the person you are intended to be.'

Hence, more than solely feeling being part of a broad, reliable structure and adopting a psychological construct, a sense of the active creation of group norms and values is present. This is enhanced additionally by the reciprocal support from other couples and community members, who communicate and follow each other's' ideas of a sound spiritual preparation. This was elaborated by Jane:

'Both, our Community friends and the priests, made us feel that we did things correctly. They affirmed us in a way. [...] After the service in St. Stephen's, we met and discussed how to prepare.'

By placing reliance on the opinion of the Community, the group functions as an advisor, sharing ideas and experiences, and moreover provides a feeling of security. In conclusion the couple learns from other Community couples and the priests, serve as a controlling body, in a way, that sees to it that the couple and their wedding stay within the margins of the strong-belief Community, Roman-Catholic, Christian tradition.

\section{The preparation of the wedding feast}

Spiritual preparation constitutes the beginning of a causal chain, which ultimately leads to freedom from worldly desires and thus to true complete happiness. By preparing spiritually, the couple secure themselves God's benevolent guidance, allowing them to refrain from abundant commercial ideas that normally dominate weddings. In other words, they adjure their worldly desires, ideas of their self and their wedding by trusting in divine providence. The worldly preparation was dominated by the belief that only God knows what they really need or wish for, therefore only he can provide them with exactly that. Only by consciously relinquishing their expectations can they truly be free and pure in their being. Jane claimed:

'After I accepted to receive anything God would give me, I realised that my main request was to go for a walk and pray the rosary with Aaron (...). I mean, although it was important to me how the celebration of the wedding looked like, I just knew, that God would take care of it.'

More than being an easy achievable state, this trustful attitude, is perceived as a desirable outcome of a learning process, only possible by absolute dedication to God. Daniel, for example, reported it being difficult for him to let go of everything. Before the wedding he went through

Journal Title

Volume \#, Issue \#, 20\#\#, https://<websitelink>.com

(C) Common Ground Research Networks, Author(s) Name(s), All Rights Reserved.

Permissions: cgscholar.com/cg_support

ISSN: \#\#\#\#-\#\#\#\# (Print), ISSN: \#\#\#\#-\#\#\#\# (Online)

https://doi.org/\#\#\#\#\#\#\#\#\#\#\#\#\#\#\#\#\#\#\# (Article) 
phases of normal organisational and emotional distress of planning, leading to physical illness. Daniel associated this with God asking him to put more trust upon him:

'Then God showed me that I shouldn't have been stressing myself out: I got a terrible angina, couldn't speak at all and had to be in bed. I could not organise anything anymore, so I had to let it go. This was very hard for me to accept, but then I saw, that all the organisational parts aren't what a wedding is about, anyway! So I let go of everything and trusted in God, because everything was going to be fine! This was a feeling arising in me, comforting me and giving me security.'

Hence, strong belief Community weddings are characterised by a special bond with God, although they follow a generally set, roman-catholic liturgy. Through the community's shared perception of true reality they can experience absolute happiness that solely God can send upon them. As happiness is perceived to only be achievable by asking God through intensive praying, the attendance of Community members at a wedding is of vast importance, as John explained:

'They [Community wedding guests] are not only an audience, they also celebrate the service and worship God intensely. They ask the Holy Spirit to come down on the spouses in an honest and intense way.'

Community members perceive this to be expressed in the 'joyful eyes' (John), 'by their honest faces, their honest laughs' (Jane). Here again the participants' longing for authentic emotions is salient and attributed as an experience of truthfulness towards God himself and the person's engagement with him. As only Community members are fully able to understand this concept, tasks essential to the ceremony are exclusively entrusted to these, as Daniel explained:

'I have selected best men, who have been involved in our church. This was important to me because, I think only they could have supported us properly. They know what a Christian wedding and thus marriage is really about and I can rely on them.'

Despite the fact that the same occasion is celebrated in a group, the Community members do not perceive this group as equal. Based on their belief a unified inner circle within this group exists, which assumes to know the ultimate truth. They discriminate unnoticeably against nonCommunity members by passing on only unessential elements of the worldly organisation to them. Whilst 'the wedding and the reception - everything [is] very much inspired by other Charism friends and their weddings' (Jane), family and friends who are not belonging to the Community are invited to take care of 'all the little aesthetic things, like flowers, setting the tables' (Sharon). Through the individual's transformation and dissociation of worldly desires, help regarding superficial organisational elements from non-community support can easily be accepted, as aesthetic expectations lose their relevance. Aaron explained:

'Through prayer and the focus on God, everything else was not important to us. "Shall the flowers be white or red?" - "Whatever". Jane's mum wanted to decorate the castle [in which the reception took place] - "Go for it". "Should we get to the church by a fancy Mercedes or an old VW Golf?" - "Who cares?". "Shall the invitations be pink, gold or red?" - "They're all nice colours!",

\footnotetext{
Journal Title

Volume \#, Issue \#, 20\#\#, https://<websitelink>.com

(C) Common Ground Research Networks, Author(s) Name(s), All Rights Reserved.

Permissions: cgscholar.com/cg_support

ISSN: \#\#\#\#-\#\#\# (Print), ISSN: \#\#\#\#-\#\#\#\# (Online)

https://doi.org/\#\#\#\#\#\#\#\#\#\#\#\#\#\#\#\#\#\#\# (Article)
} 
In the same way, this accounts for the concept of being a beautiful bride, as it is linked to spiritual beauty (West, 2003). On behalf of that, cultural and, moreover, own expectations of a bride's appearance are taken away from her by herself and the Community, for the purpose of focusing on the role of God in a wedding and a Christian marriage. Through this, brides automatically feel beautiful as they are pure and pious, or in Sharon's words 'I was a beautiful bride-well... I am also a real Christian.'. A bride, in the strong-belief context, hence perceives her appearance as more than representing beauty through being a projection screen for contemporary and cultural ideals. Her spiritual inner life, her Christianity, is her beauty, which is only reflected in her outer appearance. This, however, does not mean that strong-belief Community brides reject traditional dresses and beauty ideals. It is more that they are valued less. Jane, for instance:

'It's normal to have some elements, like a white wedding dress, a smoking, a reception and so on, this shouldn't be something only white-weddings are allowed to have. It's just less important to us.'

The difference in the mental setting towards beauty caused demands distinguishing from popular wedding culture. Christian values therefore supersede mundane needs.

\section{Wedding-related conflicts and conflict strategies}

The majority of external and internal wedding related conflicts described in literature (i.e. Lowrey, Shrum, 1997; Corrado, 2002; Nelson, Otnes, 2005; Nelson, Deshpande, 2011) did not seem to account for Community couples in this study. Arguments with the partner were not perceived and described as conflicts but as disagreements or differences in expectations, which are a possibility to transform and intensify affiliation and understanding in the relationship. This was portrayed in Sharon's response:

'Of course, Andy and I sometimes had different expectations! But we spoke with each other and prayed bot, together and alone. Through the love God sent us we tried to understand the partner and ourselves. So he deepened our relationship.'

The active way of working on and in a relationship was therefore related to God and him, himself, who is transmuting it by enhancing love. One could argue that participants absolve themselves in this way from the individual's responsibility of the transformation's ownership by their trust to be on the divine path. The belief that 'everything that God creates, that he determines, all his influences, are good' (Andy) can therefore be integrated in the participants' conflict resolution, as they know to be on the divine path by dedicating the problems and its solutions to God. Therefore participants employed Christian values in order to handle conflictladen situations and to perceive themselves as being agreeable with God. Sue demonstrated this in her answer:

'In order to find compromises, you have to respect the other one and their thoughts. This has a lot to do with love and respect for the other one. This is why it has something to do with Christianity, in my opinion. Christianity is about love and if you live Christianity, you have no other choice than to love.'

\footnotetext{
Journal Title

Volume \#, Issue \#, 20\#\#, https://<websitelink>.com

(C) Common Ground Research Networks, Author(s) Name(s), All Rights Reserved.

Permissions: cgscholar.com/cg_support

ISSN: \#\#\#-\#\#\#\# (Print), ISSN: \#\#\#\#-\#\#\#\# (Online)

https://doi.org/\#\#\#\#\#\#\#\#\#\#\#\#\#\#\#\#\#\#\# (Article)
} 
Information regarding this kind of conflict coping strategy showed to have two origins. Participants can 'learn that from [their] trusted priest' (Daniel). In other words, spiritual leaders educate the couple how to deal with arguments in a Christian relationship. Moreover participants reported conflicts on micro (intrapersonal ambivalence), meso (disagreements with the partner) and macro (organisational and worldly issues) levels to be rare because of their focus on belief. If they felt stressed because of disagreements, they provoked a deliberate disaffection from the conflict by a conscious recollection on belief, portrayed in Sue's answer:

'When I experienced issues, I took a step back and discussed with Daniel what really mattered: the liturgy. (...) We knew, everything was going to be fine, because the most important element was the liturgy and that God would come upon us at that moment.'

Through the decision to seclude oneself regarding any other expectations than those from the Community, a couple shows to be shielded from cultural ambivalence. This, however, is only possible as the spouses have a shared perception of meaningful rites. Helen, for example, claimed:

'My husband is from Italy and I'm from Austria, but we didn't incorporate any customs regarding our national origin. For us the Roman-Catholic rituals have been of major importance and hence we only considered them.'

Ignoring other values and ideas also appealed for sociological ambivalence. Through attributing 'they can't understand our attitude towards truth' (Sharon) to non-Roman Catholic people's perception, they take other opinions less seriously, even if they derive from their own family, being demonstrated in Jane's answer:

'We just ignored them [family's expectations]! Because it's not about arguing with the family, it is about the sacrament of marriage.'

In conclusion one could argue that the protection from conflicts and ambivalence is rooted in the couples' identification with strong belief Community values and Roman Catholic rituals on one hand and on their ultimate trust in God, even in conflict situations, on the other hand. Belief can hence be directly linked to conflict resolution as having a relativizing effect on worldly, cultural and sociological matters.

\section{Expressing identity through the wedding-celebration}

More than expressing an identity, as to evoke specific impressions in other people's minds (Goffman, 1959), the interviewed people of strong belief Communities perceived themselves to express a consciously recognized authentic inner state, which was found during spiritual preparation. This evoked the feeling of presenting the authentic self and an authentic relationship (Wood et al, 2008). As honesty is an important Christian value, the strong belief Community couple feels the need to express their true identity, wherever they are, no matter which audience is present. This was portrayed in Daniel's response:

\footnotetext{
Journal Title

Volume \#, Issue \#, 20\#\#, https://<websitelink>.com

(C) Common Ground Research Networks, Author(s) Name(s), All Rights Reserved.

Permissions: cgscholar.com/cg_support

ISSN: \#\#\#\#-\#\#\#\# (Print), ISSN: \#\#\#\#-\#\#\#\# (Online)

https://doi.org/\#\#\#\#\#\#\#\#\#\#\#\#\#\#\#\#\#\#\# (Article) 
'I was unsure and intimidated by revealing my true identity to them [mundane friends]. But I knew it was necessary, because I can't get married without God, without our belief, without things, expressing our belief. This wouldn't have been honest and I couldn't have got married like that. I wanted the wedding to be authentic and I had to stand up for my belief.'

In Goffman's terms, Daniel perceives himself to express his backstage identity, whilst, in favour of his belief, deliberately rejecting performances of Front stage roles. Once this identity is found and established successfully with the partner, little else than Roman-Catholic expectations can influence them in their behaviour or perception. Sue, for example:

'We wanted to show, that we are authentic. We won't adapt to contemporary putative ideals, to opinions, to anything. We will remain in God and he will do us good.'

Through God's providence the couple is enabled to block out everything irrelevant to their Community's belief, while allowing themselves to be comfortable as being their perceived true selves. Moreover, the Community's support gives the freedom to express the identity unrestrictedly, without fear of being unaccepted or repressed within their community. Even if members do not get along well, they help each other. Sharon, for instance, claimed:

'Martin appeared to be unlikeable to me and I knew he felt similar about us. However, I always appreciated him as God's being and then, during our engagement, he really helped us a lot.'

Therefore, the couple's experience regarding their relationship with God and the unconditional support from Community members affirm the couple by enhancing social stability to express what the spouses perceived as true identity.

\section{Discussion}

The analysis confirmed Rubio's (2003) suggestion of the spiritual leaders' and Christian literature's importance in the preparation and celebration of weddings for Roman-Catholic couples. Through the active engagement with Christian books and discussions with priests, Roman-Catholic values were re-created in the participants' minds and therefore internalised as their own. These concepts were not only applied to the wedding and marriage, but also to interpersonal relationships in general. At the same time the individual's self underwent significant changes, consistent to some extent with Spinelli's (2001) concept of self, as a flexible entity. However, after the perceived 'true' self within the community was created, it was less susceptible to change in the face of different social interactions, relationships, and contexts. The "true" self was then perceived as godly and original. This rejects Tajfel's (1996) hypothesis of the self as prone to change in context of any interpersonal relationship. The perceived in-group of fellow worshippers enhanced and stabilised the process of self-discovery, by accepting the individual and excluding mundane expectations such as worldly desires.

Confirming the work of Klapp (1969), the results suggest that the individual's identity is set up as a frame of reference that was built by situating oneself in the context of meaningful social settings, creating a feeling of security (Stone, 1962). Moreover, the present findings are aligned with Turner's (1985) notion that individuals share a social reality with people of their own social category. However, the present results extent Turner's (1985) notion by indicating that the attribution of truth as being exclusive to their own social category may result in shielding the

\footnotetext{
Journal Title

Volume \#, Issue \#, 20\#\#, https://<websitelink>.com

(C) Common Ground Research Networks, Author(s) Name(s), All Rights Reserved.

Permissions: cgscholar.com/cg_support

ISSN: \#\#\#-\#\#\#\# (Print), ISSN: \#\#\#\#-\#\#\#\# (Online)

https://doi.org/\#\#\#\#\#\#\#\#\#\#\#\#\#\#\#\#\#\#\# (Article)
} 
individual's identity from worldly and mundane influences. Therefore, the idea that different people live in different realities legitimized giving little consideration to out-group norms and expectations.

This also explains why the identification with a community, being a subculture within a broad mainstream culture, did not increase the probability of cultural and sociological conflicts. Although previous research linked sociological ambivalence (Lopata, 1991; Zaniecki, 1965) and cultural ambivalence (Hajda, 1968; Otnes, Lowrey \& Shrum, 1997) to wedding preparations, the present study did not identify any of these conflicts in the couples' narrative accounts. Instead, the couple's shared perception of reality resulted in rejecting and ignoring families' and mundane friends' expectations regarding the ceremony. Also, internal ambivalence and interpersonal conflicts with the partner (cf. Bleuer, 1950) were resolved by trusting in divine providence and focusing on truthfulness and the liturgy. A feeling of freedom arose by apostatising from worldly desires and thus by dissociating oneself from own and the partners' expectations. This contributed to experiencing a stress-free wedding preparation and celebration, resonating with what previous literature defines as key-element in couples' positive experience of weddings (cf. Corrado, 2002).

The same attitude applies to the concept of beauty. Rather than following the idea of creating a flawless, beautiful image of oneself (Corrado, 2002), the participants' accounts can be associated with West's (2003) suggestions of the body as being an outward expression of the person. True beauty was therefore conceptualised as indicating moral qualities, linked to holiness. This made prominent contemporary ideals regarding the bride's appearance to be replaced by the focus on spirituality. In conclusion, the feeling of attraction was seen as a by-product of love, which is psychologically constructed by its attribution to God. True and enduring love was therefore understood as not emerging within oneself but through the divine instance, which represents love itself. As this differs in principle from the mundane concept of love, conceptualised as grounded in oneself, participants felt the need to explain their conceptualisation of love, when questioned about their wedding preparation. By elaborating the Christian construction of love, the interviewed Community members felt to make their conviction of the wedding, being a celebration of thankfulness for the gift of received love (Paul, 1997), understandable.

However, the reason for why members willingly conform to these ideas and adopt the Community's values can be found in the experience of increased quality of life through gaining a feeling of freedom. Rituals of self-denial and self-restrictions facilitated to maintain focus on identity-construction and development processes that was guided by prayers. This reveals a link between conforming to rules and perceived freedom. More than simply accepting rules, participants felt that they gained freedom through them, as they lead them to what they perceived as their true selves. Therefore, a specific attitude of Community members was salient, which can be associated with work by Wood et al (2008), suggesting an authentic identity being a combination of actively recognizing the inner state and acting according to it. Community members linked this attitude of authenticity to unique truthfulness and real happiness. Hence, it is not accurate to say that strong belief Community weddings can be defined by implementing specific, predetermined and religious social codes in the celebration (Rubio, 2003). Members of strong belief Communities rather attributed a unique attitude of truthfulness and real happiness to the application of those codes which distinguishes them from profane weddings. Therefore, the

\footnotetext{
Journal Title

Volume \#, Issue \#, 20\#\#, https://<websitelink>.com

(C) Common Ground Research Networks, Author(s) Name(s), All Rights Reserved.

Permissions: cgscholar.com/cg_support

ISSN: \#\#\#\#-\#\#\#\# (Print), ISSN: \#\#\#\#-\#\#\#\# (Online)

https://doi.org/\#\#\#\#\#\#\#\#\#\#\#\#\#\#\#\#\#\#\# (Article)
} 
perception of a deeper psychological construct, as definition for weddings in the community, becomes salient. Although the ceremony structure itself does not necessarily differ from worldly marriages in a Christian context, the group's unified belief makes them share a reality of true happiness through God.

In conclusion this study found that the wedding ritual reaffirmed the social bond with the group, as Turner (1969) and Van Gennep (1960) suggested. This happened rather by the conscious elevation and communication of the group's belief and values, than by only implementing predetermined ways of carrying out the ritual, to keep it sacral, as Bouissac (1990) suggested.

While the current study offered a discursive approach to understand conceptualisations of weddings in strong-belief Communities, a number of caveats need to be taken into consideration. The first limitation addresses the flexibility of the method that allows a wide range of analytic options. It needs to be noted that the researcher had chosen to select and arrange certain themes based on how conceptualisations of weddings can be explained. In doing so, it is to be suggested that some of the phenomenological values have been undermined by seeing participants' understandings not through their 'eyes' but through a 'bi-focal lens' (the participant's and the researcher's) or a 'tri-focal lens' (the participant's, the researcher's and the theory's). The second limitation addresses possible recall-biases, which the present study's design is prone to. Participants may have forgotten stressful events and conflicts that arose as part of their wedding preparation. Lastly, it needs to be kept in mind that the qualitative nature of the present approach does not allow to make generalisations.

However, although these limitations need to be taken into consideration, the present research contributed to an understanding of the experiences of strong belief Community spouses regarding the construction of their wedding, in particular the construction of identity within the community and its representation during the celebration. In doing so, the present analysis revealed how group norms are personally reconstructed and group values internalized as personal mental property.

\section{REFERENCES}

Bandura, Albert. "Going global with social cognitive theory: From prospect to paydirt." In Applied psychology, pp. 65-92. Psychology Press, 2012.

Bleuler, Eugen. Dementia Praecox or the Group of Schizophrenias. New York: International University Press. 1950

Bouissac, Paul (1990). "The profanation of the sacred in circus clown performances." By means of performance: Intercultural studies of theatre and ritual, 185-283.

Journal Title

Volume \#, Issue \#, 20\#\#, https://<websitelink>.com

(C) Common Ground Research Networks, Author(s) Name(s), All Rights Reserved.

Permissions: cgscholar.com/cg_support

ISSN: \#\#\#-\#\#\#\# (Print), ISSN: \#\#\#\#-\#\#\#\# (Online)

https://doi.org/\#\#\#\#\#\#\#\#\#\#\#\#\#\#\#\#\#\#\# (Article) 


\section{JOURNAL TITLE}

Corrado, Marisa. "Teaching wedding rules: How bridal workers negotiate control over their customers." Journal of Contemporary Ethnography 31.1 (2002): 33-67.

Goffman, Erving. The presentation of self in everyday life. London: Harmondsworth, 1978.

Gross, Edward, and Gregory, Stone. "Embarrassment and the analysis of role requirements." American Journal of Sociology 70.1 (1964): 1-15.

Hajda, Jan. "Ambivalence and social relations." Sociological Focus 2.2 (1968): 21-28.

Hussler, Edmund. Phänomenologische Psychologie. Vorlesungen Sommersemester, 1925.

Ingraham, Chrys. White weddings: Romancing heterosexuality in popular culture. Routledge, 2009.

Klapp, Orrin. Collective Search for Identity. New York: Holt, Rinehart, and Winston, 1969.

Leeds-Hurwitz, Wendy. Wedding as text: Communicating cultural identities through ritual. Routledge, 2002.

Libreria Editrice Vaticana. Catechism of the Catholic Church. Vatican: Editrice Vaticana, 2000.

Lopata, Helena Znaniecka. "Role theory." Social roles and social institutions: Essays in honor of Rose Laub Coser (1991): 1-11.

Nelson, Michelle and Sameer Deshpande. Love without Borders: Examination of Cross Cultural Wedding Rituals. In Otnes, Cele and Lowrey, Tina (Eds.). Contemporary Consumption Rituals: A Research Anthology (pp. 125-148). New Jersey: Erlbaum, 2004.

Nelson, Michelle R., and Cele C. Otnes. "Exploring cross-cultural ambivalence: a netnography of intercultural wedding message boards." Journal of Business Research 58.1 (2005): 8995.

Otnes, Cele C., and Elizabeth Pleck. Cinderella dreams: The allure of the lavish wedding. Vol. 2. Univ of California Press, 2003.

Otnes, Cele, and Linda M. Scott. "Something old, something new: exploring the interaction between ritual and advertising." Journal of Advertising 25.1 (1996): 33-50.

Otnes, Cele, Tina M. Lowrey, and L. J. Shrum. "Toward an understanding of consumer ambivalence." Journal of Consumer Research 24.1 (1997): 80-93.

Patton, Michael Quinn. Qualitative evaluation and research methods. SAGE Publications, inc, 1990.

Paul, John. The Theology of the Body. Human Love in the Divine Plan. Boston: Pauline Books \& Media, 1997.

\footnotetext{
Journal Title

Volume \#, Issue \#, 20\#\#, https://<websitelink>.com

(C) Common Ground Research Networks, Author(s) Name(s), All Rights Reserved.

Permissions: cgscholar.com/cg_support

ISSN: \#\#\#\#-\#\#\# (Print), ISSN: \#\#\#\#-\#\#\#\# (Online)

https://doi.org/\#\#\#\#\#\#\#\#\#\#\#\#\#\#\#\#\#\#\# (Article)
} 


\section{JOURNAL TITLE}

Pleck, Elizabeth Hafkin. Celebrating the family: Ethnicity, consumer culture, and family rituals. Harvard University Press, 2000.

Rosenblatt, Paul C. and Roxanne Anderson. Interaction in farm families: Tension and stress. In Coward, R.T. \& Smith, Jr. W.M. (Eds.). The family in rural society (1981): pp. 147166.

Rosenthal, Carolyn J., and Victor W. Marshall. "Generational transmission of family ritual." American Behavioral Scientist 31.6 (1988): 669-684.

Rubio, Julie Hanlon. A Christian theology of marriage and family. Paulist Press, 2003.

Sherif, Muzafer. "A study of some social factors in perception." Archives of Psychology (Columbia University) (1935).

Smith, Jonathan A. "Evolving issues for qualitative psychology." British Psychological Society, 1996.

Smith, Jonathan. A. and Virginia Eatough. Analysing qualitative data in psychology. Sage Publications Ltd, 2007.

Smith, Jonathan. A. and Mike Osborn, M. Interpretive phenomenological analysis, Qualitative psychology. Sage, London, 2003.

Smith, Jonathan A. Qualitative Psychology: A Practical Guide to Research Methods. London: Sage, 2008.

Smith, Jonathan A., Maria Jarman, and Mike Osborn. "Doing interpretative phenomenological analysis." Qualitative health psychology: Theories and methods (1999): 218-240.

Spinelli, Ernesto. The Mirror and the Hammer: Challenging Orthodoxies in Psychotherapeutic Thought. London: Sage, 2004.

Stein, Edith Werke. (2000). Knowledge and faith (Vol. 8). Washington: ICS Publications.

Stone, Gregory P. Appearance and the Self. In Arnold Rose (Ed.). Human Behavior \& Social Process (1962):pp. 86-118. Boston: Houghton Mifflin.

Tajfel, Henry. Social groups and identities. Developing the legacy of Henri Tajfel. Edited by: Peter Robinson. University of Bristol, UK, 1996.

Turner, Victor. The ritual process: Structure and anti-structure. Chicago: Aldine Publishing Company, 1969.

Van Gennep, Arnold. The rites of passage. University of Chicago press, 2019.

Journal Title

Volume \#, Issue \#, 20\#\#, https://<websitelink>.com

(C) Common Ground Research Networks, Author(s) Name(s), All Rights Reserved.

Permissions: cgscholar.com/cg_support

ISSN: \#\#\#-\#\#\#\# (Print), ISSN: \#\#\#\#-\#\#\#\# (Online)

https://doi.org/\#\#\#\#\#\#\#\#\#\#\#\#\#\#\#\#\#\#\# (Article) 


\section{JOURNAL TITLE}

Wengraf, Tom. Qualitative research interviewing: Biographic narrative and semi-structured methods. Sage, 2001.

West, Christopher. Theology of the Body Explained: A Commentary on John Paul II's" gospel of the Body". Gracewing Publishing, 2003.

Wood, Alex M., et al. "The authentic personality: A theoretical and empirical conceptualization and the development of the Authenticity Scale." Journal of Counseling Psychology 55.3 (2008): 385 .

Znaniecki, Florian. Social relations and social roles. Ardent Media, 1965.

Table 1. Demographic Information

\begin{tabular}{|c|c|c|c|c|c|}
\hline Participant & Age & Community & Years of Marriage & Nationality & Occupation \\
\hline Jane & 31 & Loretto, CL & 2 & British & $\begin{array}{l}\text { Maternity } \\
\text { Leave/Art } \\
\text { Historian }\end{array}$ \\
\hline Aaron & 28 & Loretto, CL & 2 & German & $\begin{array}{l}\text { Research } \\
\text { Assistant }\end{array}$ \\
\hline Sue & 25 & Loretto & 2 & Austrian & Doctor \\
\hline Daniel & 30 & Loretto & 2 & Austrian & $\begin{array}{l}\text { Pastoral } \\
\text { Worker }\end{array}$ \\
\hline Sharon & 29 & $\mathrm{CL}$ & 4 & German & Architect \\
\hline Andy & 30 & CL & 4 & British & Journalist \\
\hline Helen & 25 & $\begin{array}{c}\text { Oblaten } \\
\text { Community }\end{array}$ & 3 & Austrian & $\begin{array}{c}\text { Maternity } \\
\text { Leave/ } \\
\text { Teacher }\end{array}$ \\
\hline John & 27 & $\begin{array}{c}\text { Oblaten } \\
\text { Community }\end{array}$ & 3 & Italian & $\begin{array}{l}\text { Graphic } \\
\text { Designer }\end{array}$ \\
\hline
\end{tabular}

